\title{
Historical Review
}

\section{Return of function after spinal cord transection}

\author{
RF Heimburger*,1 \\ ${ }^{1}$ Birmingham, AL, USA
}

\begin{abstract}
Many able investigators have shown electronic conduction across the transected spinal cords of a variety of animals. LW Freeman reported return of function in paralyzed extremities after spinal cord section and transection in rats, cats and dogs before Medline searches could be performed online. This summary of Freeman's reports will lead today's investigators to his publications methods and successes.
\end{abstract}

Spinal Cord (2005) 43, 438-440. doi:10.1038/sj.sc.3101748; Published online 5 April 2005

Keywords: spinal cord transection; return of function; paraplegia care; plasma clot; axonal regrowth; scarring blockage; bladder control; trypsin

\begin{abstract}
Return of Function after Spinal Cord Transection has been a perennial problem. In the 1950s and 1960 s the Russians reported success in Man using Trypsin and other agents. The reports made great promises of return to function and in the 1960s. Dr William Windle (one of the great names in nerve regeneration) was sent by the USA to Russia, to investigate the claims. On his way to Russia he and his wife called in at Southampton and Dr Windle came to see my laboratory and to discuss the work I was doing at that time. On his return to the USA he tried to reproduce the work that he had been shown but was unsuccessful. I visited Windle some years after this and spent a long time with him. He was very disillusioned about the Russians' reported successes.
\end{abstract}

This review of Freeman's work is, I think, of great historical interest.

Editor

\section{Introduction}

Return of function after spinal cord injury (SCI) is the ultimate goal of spinal cord investigation in experimental animals. Before World War II it was apparent that function lost due to spinal cord and spinal nerve root damage does not return. After World War II several talented investigators, who had cared for spinal cord injured military personnel, were inspired to learn if and how the permanent loss of function due to spinal cord and nerve root injury could be reversed.

LW (Bill) Freeman, ${ }^{1}$ showed, better than other investigators, that function does return if laboratory animals are kept healthy and alive long enough.

*Correspondence: RF Heimburger, 400 University Park Drive, Apt G-25, Birmingham, AL 35209, USA
Freeman's papers were published before Medline searches could be performed online.

This summary is intended to provide today's investigators computerized access to Freeman's published reports of return of significant function after spinal cord and nerve root section in rats, cats and dogs.

\section{Methods}

Freeman learned how to keep animals alive long enough for function to return through the growth of axons past sections and transections of spinal cords and spinal nerve roots. ${ }^{3}$ SCI animals, kept in standard laboratory cages, caught and injured their insensitive, paralyzed extremities in the wire mesh of cage floors. Even if they survived long enough, their limbs were too damaged to function. Suspending paraplegic dogs in slings stopped damage to paralyzed, insensitive extremities long enough to show functional return. ${ }^{4}$ Function returned best when animals were allowed to move freely on smooth surfaces covered with clean sawdust. After spinal cord or nerve root section, all animals in Freeman's laboratory had their bladders emptied by gentle pressure three times each $24 \mathrm{~h}$ for about 2 weeks, until bladder and bowel functioned automatically. Bladder emptying was easier and more complete in female animals. High protein diet provided nutrients for better health, decreased deterioration of flaccid muscles, and encouraged axonal regrowth. Devoted care by laboratory personnel was a requirement for success. ${ }^{2-4}$

\section{Results}

Using this care of paraplegic (SCI) animals after spinal cord and nerve root transection and hemisection, Freeman was able to show return of function in hundreds of rats, cats and dogs, with less success in 
monkeys, which are much harder to keep alive. No reports after Freeman's have claimed the degree, or consistency of functional return he observed. Electronic conduction has been demonstrated across areas of spinal cord transection, but there have been no clear reports of functional return.

With hours of microscopic viewing of longitudinal sections of beautifully stained spinal cords that had been sectioned or transected many months before, Freeman saw, and showed others, many axons in the proximal spinal cord above the transection growing toward the isolated distal segment below the sections or transection. Unless adequately treated, these axons curl up in neuroma-type bundles when they reach the scar tissue at the site of transection or hemisection. When confronted by the more rapid growth of scar tissue, axons were not able to grow past the transection or hemisection to reach the distal cord and provide return of function. The race between downward axonal regrowth and scar tissue growth was invariably won by scar tissue growing more rapidly across the spinal cord. Freeman found that axons severed within the spinal cord and nerve roots have a 'relentless compulsion' to grow until they reach tissues that provide return of function, or are blocked by scar tissue, where they continued to grow in circles to form neuromata. ${ }^{3}$

Ways were sought to increase the rate of axonal growth so as to get them past the scarring in the area of section, before being blocked by faster growing scar tissue. The minimal increase in axonal growth rate achieved was not sufficient to stop axons from tangling in the developing scar tissue to form neuromata at the transection site. ${ }^{5}$

Slowing scar formation with low doses of X-ray therapy ${ }^{13}$ demonstrated that decreasing growth of scar tissue at the site where the spinal cord was cut helps regrowing axons extend past the scar tissue barrier. From there, axons can grow at their own rate into the distal cord to provide return of function. ${ }^{5}$

\section{Biochemistry}

Professor Donald Bowman suggested using trypsin to slow scar formation in the cut spinal cord. At first this material was instilled intrathecally to the site of transection through externalized thin plastic tubes. ${ }^{4}$ This technique provided encouraging return of voluntary function, including walking and in some cases even jumping on previously paralyzed hind legs. Eventually trypsin injected intramuscularly for several days after spinal cord section provided the same benefit. ${ }^{6}$ Axons were seen microscopically growing from the proximal spinal cord, past the area of diminished scarring into the distal segment of the isolated spinal cord.,4,6 Many animals treated with trypsin prepared by Bowman's method showed significant return of function after spinal cord hemisection or transection. Longitudinal sections of trypsin-treated animals showed axons arising in the proximal spinal cord and traced through the diminished scarring into its distal segment. Control animals receiving placebo had less return of function, and growing axons were found to be blocked from reaching the distal spinal cord by dense scarring. ${ }^{3,4,6}$

In one of his most spectacular experiments, Freeman used a very sharp knife to cut a $2 \mathrm{~cm}$ segment out of the spinal cord of a dog. To bring the two cleanly severed ends of the cord back together, he removed an underlying vertebra. Plasma clot was used to hold the two ends of the cord together within the tightly sutured spinal dura mater. Trypsin was administered intramuscularly as in other animals that showed return of function. The dog remained paraplegic for more than a year, but eventually became able to stand on all four legs and walk short distances. Her spinal cord sections showed multiple axons crossing the area where the segment of cord had been cut and removed. The removal of almost two thoracic segments of spinal cord with its neurons did not prevent the return of function in the dog's hind legs. Downward growth of axons seemed to provide the needed connection between the isolated distal end of the spinal cord and its cephalad control centers. Freeman did not publish a report of this outstanding success, hoping to be able to repeat it, but did not have the opportunity (Figure 1).

Freeman did not investigate how far down the spinal cord regrowing axons must extend in order for function to return. The time between spinal cord section and return of function did not seem sufficient for the

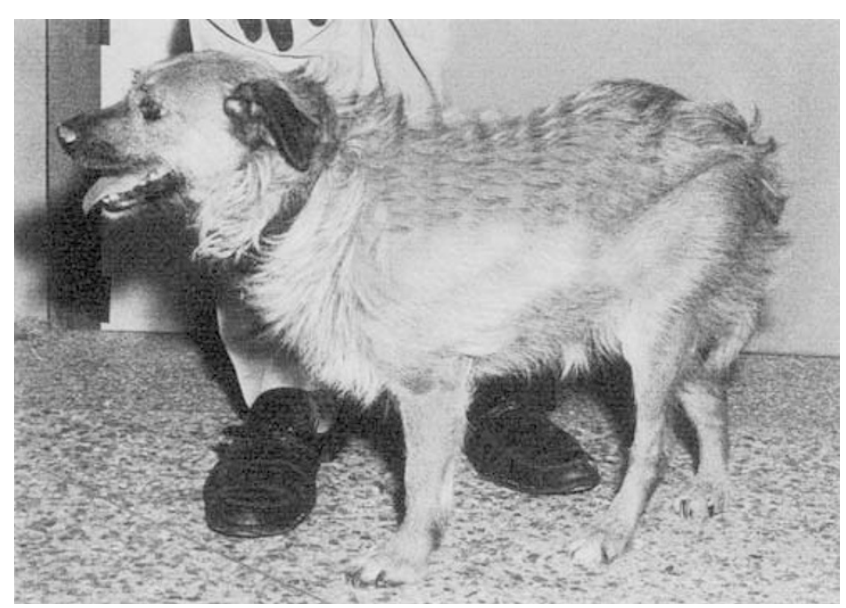

Figure 1 This dog had $2 \mathrm{~cm}$ of her spinal cord removed. In order to bring the cut ends of the spinal cord back together it was necessary to remove the underlying vertebra. The cleanly cut ends of the spinal cord were brought back together and held in place with plasma clot before the dura mater was tightly closed. The dog received injections of trypsin and was paraplegic for about a year. She gradually regained some sensation in her paralyzed lower extremities, and then strength enough to stand on all four extremities, and finally walk a few steps, before her legs gave out and she was forced to sit down. Note the relative shortening of her torso, due to the loss of a vertebra. Longitudinal microscopic sections of her spinal cord showed many axons growing from the superior segment into the inferior segment. Freeman did not publish the result of this investigation, prior to his death 
regrowing axons to reach muscle end plates and excite voluntary muscular activity in the previously paralyzed animal's hind legs. It seems more likely that the growing axons synapsed with motor neurons in the distal segment of the spinal cord. It will be important to learn how far axons must grow before muscular function returns.

Freeman's critics claimed that he did not section the spinal cord completely in the animal showing functional return. With each spinal cord section he and the resident physician in training lifted up both ends of the cord so that its cross section could be seen in both its superior and inferior ends. During much of the trypsin investigation, spinal cord hemisection was used. The angled knife was seen passing through the cord from its anterior to posterior aspect. Nerve roots were sectioned and reanastomosed using plasma clot. The roots were purposely switched, so that no roots were reanastomosed to their original source root. ${ }^{7,8}$ This demonstrated the adaptability and plasticity of spinal cord and brain neurons to provide appropriate voluntary function when connected to motor and sensory endings different from their original ones.

To carry this adaptability/plasticity further, nerve roots superior to spinal cord section were dissected free, and while still connected superiorly, cut and imbedded into the distal segment of cord inferior to its transection. This provided significant return of function in many animals. $^{9-11}$ Experiments to bring roots from inferior to the site of hemisection or transection, past it to implant in the superior segment of spinal cord, were just getting underway when Freeman contracted the illness that ended his life, ${ }^{12}$ but also showed significant return of function.

Freeman's lifelong care for the spinal cord injured (para and quadriplegic SCI) men and women started during his World War II military service, and continued with enduring friendships throughout his life. He took paraplegic friends fishing for large muskellunge in a northern Wisconsin lake, and often invited them into his home to form lasting friendships with his wife and six children. In turn, paralyzed veterans helped raise funds for spinal cord research. In their search for government assistance, handicapped access into public buildings, arranging for conferences and resolving personal matters, Bill Freeman was regularly involved. He was an innovator, influential personally in organizing the Paralyzed Veterans of America (PVA) while he was in Military Service. During his relatively short lifetime, Bill
Freeman had the privilege of seeing a complete reversal, in life expectancy after spinal cord injury, from around 12 months after injury to an almost normal life span.

\section{Acknowledgements}

Helpful information from LW Freeman's children, Dr Julia, Bill, Bob MD and Leslie is appreciated, as is computer expertise from Doug Heimburger, MD.

\section{References}

1 Freeman LW. Return of function in mammals after transecting lesions. Ann NY Acad Sci 1954; 58: 562-568.

2 Heimburger RF. Leslie Willard (Bill) Freeman - 19151969. Surg Neurol 1974; 2: 390-392.

3 Freeman LW. Experiment observation upon axonal regrowth in transected spinal cord of mammals. (A Review). Clin Neurosurg 1960; 15: 294-319.

4 Freeman LW, MacDougal J, Turbes CC, Bowman DE. The treatment of experimental lesions of the spinal cord of dogs with trypsin. J Neurosurg 1960; 17: 259-265.

5 Gokay H, Freeman LW. Drugs and spinal cord regeneration. Quart Bull Indiana Univ Med Center 1952; 14: 67-69.

6 Turbes CC, Freeman LW. Apparent spinal cord regeneration following intramuscular trypsin. Anatomical Record 1953; 117: 288

7 Freeman LW. Functional regeneration of spinal nerve roots. Quart Bull Indiana Univ Med Center 1949; 11: 43-46.

8 Freeman LW. Observation on spinal nerve root transplantation in the male guinea baboon. Ann Surg 1952; 136: 206-210.

9 Turbes CC, Freeman LW. Peripheral nerve spinal cord anastomosis for experimental cord transection. Neurol (Minneapolis) 1958; 8: 857-861.

10 Jacoby RK, Turbes CC, Freeman LW. The problem of neuronal regeneration in the central nervous system. 1 . The insertion of centrally connected peripheral nerve stumps into the spinal cord. J Neurosurg 1960; 17: 385-393.

11 Freeman LW, Turbes CC. Influence upon reflex activity of viable nerve implants into the distal segment of the divided spinal cord in paraplegic animals. Exp Med Surg 1961; 19: 270-277.

12 Perkins L, Babbini A, Freeman LW. Distal proximal nerve implants in spinal cord transection. Neurol (Minneapolis) 1964; 14: 949-954.

13 Turbes CC, Freeman LW, Gastinau DC. X-ray radiation of experimental lesions of the spinal cord. Neurol (Minneapolis) 1960; 10: 84-89. 